\title{
Peranan Orang Tua Dalam Mengembangkan Potensi Anak Berbakat (Gifted)
}

\author{
Nora Susilawati \\ Universitas Negeri Padang \\ Email: norasusilawati1973@gmail.com
}

\begin{abstract}
Abstrak
Anak berbakat merupakan anak yang memiliki kemampuan atau potensi unggul dan dapat memberikan prestasi yang tinggi, memiliki kecerdasan di atas rata-rata, kreativitas dan perkembangan kemampuannya di atas rata-rata. Abak berbakat ini memiliki kebutuhan khusus agar dapat menunjang potensi mereka bisa berkembang. Ada beberapa istilah tentang anak berbakat ini yaitu gifted, talented, bright, bahkan ada juga istilah superior dan genius. Kesemuanya harus dipahami karena memiliki kesamaan dan perbedaan secara konsep dan realitanya. Tulisan ini menggunakan istilah anak berbakat (gifted), karena anak gifted memiliki perfeksionisme dan faalangst negatif yang menyebakan munculnya masalah bagi dirinya dan orang lain dalam mengembangkan potensi diri. Perfeksionisme menuntut adanya perilaku ideal yang diharapkan dan faalangst negatif menimbulkan ketidakpercayaan diri dan kecemasan yang berlebihan. Tentu saja hal ini dapat menjadi penghambat dalam pengembangan potensi anak berbakat. Karena anak berbakat memiliki kebutuhan khusus yang harus diperhatikan, maka orang tua sebagai agen utama harus berperan penting dalam menentukan apa yang dilakukan. Orang tua harus cerdas, cermat dan aktif untuk mengatasi permasalahan yang muncul akibat kelebihan yang sekaligus juga menjadi kelemahan anak berbakat. Dengan demikian, orang tua dapat memperoleh alternatif cara bagaimana mengembangkan potensi anaknya. Selanjutnya, orang tua dapat berperan sebagai pendidik (educator), fasilitator, motivator, supporter dan role model bagi anaknya agar dapat mengembangkan potensi yang dimiliki anak berbakat. Peran yang dijalankan oleh orang tua tersebut sangat relevan dengan teori pendidikan humanistik yang melihat anak sebagai pusat, perhatian pada pengembangan potensi anak, orang tua sebagai fasilitator, motivator dan supporter dalam mengembangkan potensi anaknya.
\end{abstract}

Kata Kunci: Anak berbakat, Orang tua, Peran, Potensi anak

\begin{abstract}
Gifted children are children who have the ability or potential superior and can provide high achievement, have the intelligence above average, creativity and development of abilities above average. The talents have special needs in order to support their potential can develop. There are several terms about this gifted child, namely gifted, talented, bright, there are even terms superior and genius. All must understood because it has similarities and differences in concept and reality. This paper uses the term gufted has a perfectionism and negative faalangst that causes it to appear problems for himself and others in developing the potential of the din. Perfectionism demands the existence of ideal behaviors that are expected and faalangst negativity creates self-distrust and excessive anxiety. Of course this can be an obstacle in developing the potential of gifted children. Because gifted children have special needs that must be considered, parents as the main agents must play an important role in determining what to do. Parents must be smart, careful and active to overcome problems that arise as a result of strengths as well as weaknesses of gifted children. Thus, parents can get alternative ways to develop their children's potential. Furthermore, parents can act as educators, motivativators, facilitators, supporters and role models for their children in order to develop the potential of gifted children. The role played by the tus is relevant to humanistic education theory which sees children as the center, attention to development of children's potential, parents as facilitators, motivators, and supporters in developing their children's potential.
\end{abstract}

Keywords: Gifted, Parents, Potential child, Role

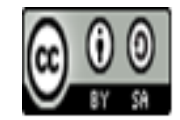

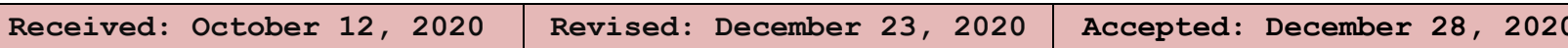




\section{Pendahuluan}

Keluarga adalah lembaga pertama dimana anak menjalani proses sosialisasi secara primer. Dalam proses sosialisasi tersebut, orang tualah yang berperan sebagai agen utama. Orang tua harus memberikan perhatian kepada anak-anaknya agar mereka dapat tumbuh dan berkembang secara baik sesuai dengan potensinya masing-masing. Salah satu yang perlu diperhatikan adalah anak yang disebut dengan anak gifted atau anak yang berbakat. Munandar (Munadar, 2012) mengemukakan bahwa anak gifted ini sering juga disebut sebagai anak talented. Mereka adalah anak-anak yang memiliki kemampuan luar biasa dan kecakapan mengerjakan pekerjaan-pekerjaan yang berkualitas tinggi. Gagne (Gagné, 2006) membedakan antara anak gifted dengan talented.

Anak gifted adalah anak yang memiliki kecakapan di atas rata-rata dalam satu domain bakat seperti intelektual, kreatif, sosio-afektif, dan sensori motorik. Sedang Talent menurut Gagne adalah penampilan (performance) yang berbeda di atas rata-rata dalam satu atau lebih bidang aktivitas. Keterbakatan anak menurut Munandar (2012) harus dirangsang sejak usia dini dan tentu saja membutuhkan dukungan dari lingkungan. Salah satu lingkungan yang harus mendukungnya adalah lingkungan keluarga. Pengembangan potensi akan mudah dan efektif jika dimulai sejak usia dini karena membutuhkan rangsangan dan tantangan untuk mencapai aktualisasi diri tingkat tinggi.

Lingkungan keluarga yang dibutuhkan adalah lingkungan keluarga yang kondusif, yang mampu memberikan pengalaman, merangsang rasa ingin tahu, sekaligus menyediakan kesempatan untuk mengeksplorasi berbagai kemungkinan dalam menemukaan jawaban. Dalam hal ini, orang tua perlu mengidentifikasi potensi yang dimiliki anaknya. Kenyataan yang terjadi adalah orang tua masih belum berperan optimal memahami dan mengembangkan bakat atau potensi anaknya. Sehingga anak berbakat yang memiliki kerentanan (vulnerability) menimbulkan berbagai masalah dalam keluarga, sekolah dan masyarakat. Dari beberapa artikel yang ditelusuri dapat diidentifikasi beberapa masalah terkait dengan anak berbakat yaitu Wahab (Rachmat Wahab, 1997) dalam tulisannya tentang pendidikan anak berbakat dan masalah-masalah yang dihadapi menjelaskan bahwa masalah-masalah yang terjadi pada anak berbakat adalah 1) seringnya terjadi konflik dengan orang lain karena tidak mudah menyesuaikan diri diri atau tunduk dengan tekanan dari orang tua, sekolah dan teman-temannya; 2) dengan kemampuan kreatif dan minatnya melakukan hal-hal baru menyebabkan mereka tidak menyukai atau lekas bosan degan tugas-tugas rutin; 3) kepekaan yang tinggi dapat membuat mereka mudah menjadi tersinggung atau peka terhadap kritik; 4) si anak merasa ditolak dan kurang dimengerti oleh lingkungannya; dan 5) skeptis terhadap diri sendiri dan orang lain.

Tulisan berikutnya adalah dari penelitian yang dilakukan oleh Ohio's State Board of Education (2012) mengungkap bahwa 85 \% anak berbakat mengalami "underaciever" karena tidak mendapatkan pelayanan pendidikan yang diharapkan dari orang tua dan sekolah, anak berbakat tidak mendapatkan stimuli untuk mengembangkan potensi dirinya, banyak mengalami "drop out"dari sekolah karena tidak memperoleh layanan akademik yang sesuai dengan kebutuhan dirinya dan sering bosan, frustasi, rasa marah serta merasa kurang berharga. Selanjutnya, penelitian Wandasari, Yetty (Wandansari, 2012) tentang Faktor protektif pada penyesuaian sosial anak berbakat menjelaskan bahwa keterbakatan intelektual membawa sejumlah konsekuensi yang dapat menghambat relasi sosial anak berbakat dengan teman sebaya. Lebih lanjut dijelaskan bahwa permasalahan dalam berinteraksi dengan teman sebayanya karena adanya perasaan terisolir dari pergaulan teman sebaya, sulit menerima kritik dan menolak otoritas.

Selain itu, tulisan dari Rusdayanti (Rusdayanti, 2019) yang menulis artikel dari hasil penelitiannya tentang Penyesuaian diri anak berbakat intelektual dengan pola asuh otoritarian mengungkap bahwa penyesuaian anak berbakat dalam pola asuh orang tua yang otoritarian meliputi cara merespon, harapan diri, dan kelebihan diri. Penyesuaian diri personal meliputi penyesuaian diri terhadap kesehatan, harapan dan kondisi diri dan penyesuaian diri secara sosial meliputi perlakuan keluarga, guru, teman dan lingkungan yang kurang memadai.

Jurnal Sikola: Jurnal Kajian Pendidikan dan Pembelajaran Vol. 2, No. 2, Th. 2020 
Berikutnya Masruroh dan Widayat (Masruroh, H \& Widayat, 2014) menunjukkan bahwa terdapat tujuh strategi dilakukan oleh orang tua dalam mengembangkan kreativitas anak berbakat istimewa yang terdiri dari aktivitas eksplorasi umum, aktivitas pilihan individu, proyek individu, bertukar ide, penyediaan fasilitas, pendorong dan apresiasi.

Berdasarkan uraian dan masalah-masalah di atas, dapat dikatakan bahwa anak berbakat merupakan anak luar biasa sebab ia memiliki perbedaan dengan anak-anak lainnya. Mereka memiliki keunggulan, namun sekaligus memiliki kelemahan terkait keunggulan yang dimilikinya tersebut. Berbagai masalah yang bisa muncul dengan adanya keunggulan dan kelemahannya itu. Beberapa artikel di atas baru mengungkap permasalahan terkait dengan anak berbakat yang tidak mendapatkan pelayanan pendidikan yang tepat di sekolah, dan bagaimana penyesuaian diri mereka melalui pola asuh orang tua yang otoritarian, sebab anak berbakat memiliki masalah yang berhubungan dengan relasi sosial dengan orang lain, dan bagaimana strategi orang tua dalam mengembangkan kreativitas anak berbakat dalam berbagai aktivitas secara individual.

Berbeda dengan tulisan yang penulis paparkan dalam artikel ini lebih memfokuskan pada peran orang tua dalam mengembangkan potensi anak berbakat tersebut. Orang tua sebagai agen utama dan yang paling terdekat dengan anak di rumah diharapkan mampu memahami anaknya yang memiliki keunggulan dan kelemahan. Namun, kenyataannya sebagian besar orang tua belum mampu memahami tentang potensi anak dan bagaimana mengembangkannya. Terkait dengan itu, anak berbakat menjadi tidak terarah dalam beraktivitas dan kemampuan potensi yang tinggi dimiliki oleh anak berbakat akhirnya cenderung menunjukkan kemampuan di bawah kemampuan yang sebenarnya. Penelitian yang pernah dilakukan oleh Hawadi (Hawadi, 2000) menjelaskan bahwa kepedulian orang tua masih rendah karena adanya prinsip pada diri orang yang mengatakan "anak berbakat dapat berhasil tanpa intervensi orang tua". Padahal keterlibatan orang tua bagi anak berbakat memiliki kedudukan yang sangat strategis. Untuk itulah, mengingat pentingnya peran orang tua ini dalam mengembangkan potensi anak berbakat, maka penulis memaparkannya dalam tulisan ini. Dengan demikian dapat dirumuskan pertanyaan bagaimana peran orang tua dalam mengembangann potensi anak berbakat?

\section{Metode Penelitian}

Metode penelitian yang digunakan adalah studi kepustakaan. Metode studi kepustakaan menurut M. Nazir (Nazir, 1988) adalah teknik pengumpulan data dengan menggunakan studi penelaahan terhadap buku-buku, literatur-literatur, catatan-catatan dan laporan-laporan yang berhubungan dengan masalah yang dipecahkan. Penulis menggunakan berbagai literatur seperti buku, jurnal dan referensi relevan lainnya terkait dengan kebutuhan dalam penulisan artikel peran orang tua dalam mengembangkan potensi anak berbakat. Diharapkan dengan mendapatkan data dan informasi dari berbagai buku, jurnal dan literatur lainnya dapat mengungkap masalah peran orang tua anak dalam mengembangkan potensi anak berbakat.

Studi kepustakaan untuk mempertajam kajian konsep, teoritis, dan memperoleh informasi mengenai karya ilmiah dan penelitian yang sejenis dengan yang penulis lakukan (Danim, 2002). Berbagai informasi yang diperoleh dari berbagai literatur dapat dijadikan kajian tentang peran orang tua dalam mengembangkan potensi anak berbakat dijadikan sebagai sumber kekinian, perbaikan dan pemutakhiran dari berbagai bahan sejenis yang telah ditulis oleh beberapa penulis sebelumnya.

\section{Hasil dan Pembahasan}

\section{Pengertian Anak Berbakat}

Sebelum penulis memaparkan bagaimana peran orang tua dalam mengembangkan potensi anak berbakat, terlebih dahulu ada baiknya kita mengetahui dulu beberapa istilah dengan anak berbakat ini. Tujuan mengetahui istilah-istilah ini agar kita dapat memahami perbedaan kemampuan/keunggulan bidang apa yang dimiliki oleh anak berbakat tersebut. Dari beberapa 
literatur yang dibaca, ada beberapa istilah terkait dengan anak berbakat ini yaitu gifted, talented dan bright (Mulyadi, 2019). Menurut Hagen dan Hollingworth dalam (Hawadi, 2000), gifted berbeda dengan talented. Gifted ditujukan pada individu yang memiliki kemampuan akademik tinggi, sedang talented berkaitan dengan individu dengan kemampuan unggul di bidang seni, musik dan drama. Istilah lain yaitu bright diartikan oleh Cutts dan Musseley yaitu individu yang mampu menempuh pendidikan tingkat sekolah menengah atas (kolese) dan lancar dalam karir yang dipilihnya. Gifted diartiakn individu yang memiliki potensi yang lebih tinggi dari pada individu dengan tingkat bright, sedang talented menunjukkan pada individu yang memiliki kemampuan tidak lazim (luar biasa di bidang akademik, dan kemampuan yang tergolong superior.

Berbeda dengan Coleman, ia membedakan antara gifted dengan genius (Mulyadi, 2019). Menururt Coleman, seorang gifted belum tentu genius karena dinilai belum memberikan kontribusi unik pada lingkungannya dalam kurun waktu tertentu. Namun seorang genius adalah pasti seorang gifted. Genius menunjuk pada individu yang memiliki kemampuan tingkat tinggi dan tercermin dalam prestasi yang bermakna atau luar biasa. Sementara gifted merujuk pada individu yang memiliki kemampuan superior.

Selanjutnya, Terman mengatakan bahwa anak berbakat adalah anak yang secara global menguasai semua mata pelajaran dan bahkan berhasil menyelesaikan pendidikan di perguruan tinggi pada usia yang sangat muda. Anak seperti ini mudah dilihat dari prestasinya yang luar biasa pada seluruh bidang. Mereka memiliki keterampilan verbal yang luar biasa sebaik kemampuan spatial, berhitung dan logika sehingga memungkinkan untuk menyelesaikan soal-soal matematika maupun soal-soal mata pelajaran lain.

Berikutnya Ellen Winner (1996) dalam (Santrock, 2011) juga menjelaskan bahwa anak berbakat (gifted) adalah anak yang memiliki kecerdasan di atas rata-rata biasanya IQ di atas 130 dan punya bakat unggul di beberapa bidang seperti seni, musik atau matematika. Menurut Ellen Winner ada tiga kriteria dikatakan anak memiliki ciri berbakat yaitu :

a) Dewasa lebih dini (precocity) yaitu anak yang dewasa sebelum waktunya apabila diberi kesempatan untuk menggunakan bakat atau talenta mereka. Mereka mulai menguasai suatu bidang lebih awal ketimbang teman-temannya yang tidak berbakat. Anak ini dilahirkan dengan membawa kemampuan di domain tertentu, walau bakat yang dibawa sejak lahir itu perlu dipelihara dan di pupuk.

b) Belajar menurut kemauan sendiri. Anak berbakat berbeda dengan anak lain yang tidak berbakat. Mereka tidak membutuhkan banyak dukungan atau scaffolding dari orang dewasa. Mereka tidak mau menerima instruksi yang jelas dan sering membuat penemuan serta memecahkan masalah sendiri dengan cara yang unik terkait dengan kemampuan bakatnya. Kemampuan mereka di bidang lain boleh jadi normal atau di atas normal.

c) Semangat untuk menguasai. Anak yang berbakat tertarik untuk memahami bidang yang menjadi bakat mereka. Mereka memperlihatkan minat besar dan obsesif dan kemampuan yang kuat. Mereka punya motivasi internal yang kuat sehingga tidak perlu didorong oleh orang tuanya.

Pandangan terbaru mempesepsikan anak berbakat dengan menggunakan kriteria majemuk atau multikriteria. Misalnya pandangan USOE (United States Office of Education) dan pandangan Renzulli. Menurut USOE istilah talented, tidak dibedakaan dengan gifted atau gifted mempunyai arti yang sama dengan talented. Anak berbakat diartikan memiliki kualifikasi sebagai seorang dengan kemampuan menonjol yang memiliki performansi tinggi dan ditunjukkan dalam prestasi dalam salah satu aspek dari enam aspek yaitu kemampuan intelektual umum, pemikiran kreatif dan produktif, kemampuan akademik khusus, kemampuan kepemimpinan, kemampuan seni, dan kemampuan psikomotor.

Selanjutnya Renzulli memberi pandangan anak berbakat dengan menggunakan konsep "three ring conception"yaitu adanya keterpaduan yang bersinergi antara intelegensi (di atas rata-rata 
atau IQ melebihi 120), kreativitas yang tinggi dan pengikatn diri terhadap tugas (task commitment). Kriteria keberbakatan yang dimiliki adalah:

1. Kriteria pertama yaitu mempunyai intelegensi tinggi atau IQ di atas rata-rata $(>120)$ yang ditandai dengan kemampuan daya abstraksi, kemapuan penalaran yang tinggi serta kemampuan memecahkan masalah.

2. Kriteria kedua yaitu mempunyai kreativitas yang tinggi ditandai dengan kemampuan untuk menciptakan suatu yang baru, kemampuan untuk memberikaan gagasan-gagasan baru yang dapat diterapkan dalam memcahkan masalah dan kemampuan melihat hubungan-hubungan baru antara unsur-unsur yang sudah ada sebelumnya.

3. Kriteria ketiga yaitu mempunyai tanggung jawab terhadap tugas yang ditandai dengan ketekunan dan keuletan yang amat tinggi. Walaupun mengalami berbagai macam hambatan dan rintangan serta menyelesaikan tugas yang menjadi tanggung jawabnya dengan baik.

Terkait dengan beberapa istilah di atas, penulis menjelaskan anak berbakat dengan istilah gifted. Secara arti dan defenisi serta kriteria tentang anak gifted ini telah dijelaskan di atas. Penulis menjelaskan anak berbakat (gifted) ini karena mereka memiliki kerentanan dengan adanya perfeksionisme dan faalangst negatif yang menyebabkan permasalahan bagi anak dan orang tua dalam mengembangkan potensi anak tersebut. Perfeksionisme yang selalu menuntut sesuatu harus ideal dan tuntutan yang tinggi dapat menimbulkan permasalahan seperti tidak bisa menerima kesalahan dan kekalahan diri dan orang lain. Begitu juga dengan faalangst negatif yang memiliki rasa tidak percaya diri dan kecemasan yang berlebihan, menyebabkan anak berbakat (gifted) ini menjadi tidak berkembang potensinya. Untuk itu orang tua sebagai agen utama yang sangat strategis berperan membantu anaknya mengembangkan potensi anak tersebut.

\section{Peran Orang Tua Mengembangkan Potensi Anak Berbakat}

Untuk memaparkan bagaimana peranan orang tua dalam mengembangkan potensi anak berbakat (gifted), maka kita harus memahami dulu tentang konsep peranan. Peranan (role) merupakan aspek yang dinamis dari kedudukan (status). Apabila seseorang melaksanakan hak dan kewajibannya sesuai dengan kedudukannya dia dikatakan telah menjalankan peranannya. Peranan menentukan apa yang diperbuatnya bagi kelompok dan masyarakatnya serta kesempatan-kesempatan apa yang diberikan kelompok dan masyarakat kepadanya (Soekanto, 2009). Peranan ini penting karena ia mengatur perilaku seseorang dan peranan menyebabkan seseorang pada batas-batas tertentu dapat meramalkan perbuatan orang lain. Orang yang bersangkutan akan menyesuaikan perilakunya sendiri dengan perilaku orang-orang di kelompoknya. Peranan diatur oleh norma-norma yang berlaku. Peranan lebih menunjukkan pada fungsi, penyesuaian diri, dan sebagai proses.

Menurut Soekanto (2009: 213), peranan meliputi tiga hal yaitu sebagai berikut:

1. Peranan meliputi norma-norma yang dihubungkan dengan posisi atau tempat seseorang dalam kelompok atau masyarakatnya. Peranan dalam arti ini merupakan rangkaian peraturanperaturan yang membimbing seseorang dalam kehidupan kemasyarakatan.

2. Peranan merupakan suatu konsep tentang apa yang dapat dilakukan oleh individu dalam masyarakat sebagai organisasi atau kelompok.

3. Peranan juga dapat dikatakan sebagai perilaku individu yang penting bagi struktur sosial masyarakat.

Selanjutnya, Elly Marlihah (Elly M. Setiadi, 2011) mengemukan bahwa kedudukan dan peranan sama-sama memiliki fungsi yang terkait (korelasional), Jika seseorang telah menjalankan hak dan kewajiban sesuai dengan kedudukannya, maka ia telah menjalankan suatu peranan sosial. Sebab peranan merupakan faktor penentu apa yang seharusnya diperbuat oleh seseorang dan pemberi kesempatan bagi pemerannya.

Terkait dengan konsep peranan di atas, bila dihubungkan dengan tulisan yang penulis buat, orang tua memiliki peranan penting dalam struktur sosial keluarga. Sebagai orang tua, ia juga dapat melakukan apa yang sebaiknya dalam mengembangkan potensi anaknya, khususnya anak 
berbakat (gifted). Berikut diuraikan bagaimana peranan orang tua dalam mengembangkan potensi anak berbakat (gifted)

Wahab (Racmat Wahab, 2005) menjelaskan bahwa terdapat enam peranan orang tua terhadap keterbakatan anak yaitu:

1. Orang tua berperan sebagai pendidik (educator) dalam proses pembentukan pribadi dan moral anak sehingga menjadi dasar dalam mengembangkan kemampuan anak.

2. Orang tua sebagai guru dalam kehidupan sehari-hari anak dengan melakukan kegiatan belajar seperti membaca, menulis dan berhitung agar anak memiliki kesiapan melakukan aktivitas belajar seperti yang diharapkan oleh sekolah.

3. Orang tua sebagai motivator yaitu memotivasi anak dan mendorongnya secara langsung dan tidak langsung agar mereka dapat meyukai kegiatan belajar yang dilaksanakan.

4. Orang tua sebagai supporter yaitu memberi dukungan secara moril dan materil untuk melakukan kegiatan belajar di rumah dan kepentingannya di sekolah. Bentuk dukungan yang diberikan harus didasarkan pada prinsip-prinsip pedagogis sehingga mereka dapat memberikan dukungan yang bermakna terhadap pertumbuhan dan perkembangan anak.

5. Orang tua sebagai fasilitator yaitu memfasilitasi segala kegiatan anak dalam proses pertumbuhan dan perkembangannya. Caranya adalah dengan menciptakan lingkungan yang kondusif agar terciptanya kegiatan belajar dan bermain anak di rumah sesuai dengan kebutuhan dan perkembangan anak.

6. Orang tua sebagai model yaitu menjadi contoh dan teladan di rumah dalam berbagai aspek kemampuan dan perilaku hidup sehingga anak dapat mengikuti secara baik. Misalnya bertutur kata, kebiasaan membaca, berdialog atau berdiskusi setiap menghadapi persoalan dengan cara yang demokratis, perhatian terhadap sesama dan sebagainya.

Selanjutnya, Syafatania dan Widayat (Widayat, 2016) menjelaskan bahwa peranan orang tua dalam mengembangkan potensi anak berbakat sebagai berikut:

Pertama, memberi kesempatan anak belajar hal baru. Kesempatan untuk belajar hal-hal baru ini seperti memberi kesempatan anak untuk belajar di luar misalnya les, ekstrakurikuler, latihan dan pembalajaran lain yang dapat memberi kebebasan dan eksplorasi pengalaman anak. Dengan andanya kesempatan tersebut, maka muncul keinginan untuk mencoba dan memunculkan rasa ingin tahu yang tinggi dan dapat menjadi inspirasi untuk ide baru.

Kedua, berusaha memahami anak. Orang tua perlu memahami dan menghayati perasaan, pemikiran, dan tindakan dari sudut pandang anak. Orang tua harus mendengarkan keinginan anak, menunjukkan orang tua peduli terhadap apa yang diutarakan oleh anak. Orang tua memahami keadaan emosi anak, memberi kesempatan anak untuk mengendalikannya sendiri, dan tidak ikut campur untuk menghindari masalah besar. Orang tua bisa menindaklanjuti dengan memancing anak untuk terus berlatih, memahami apa yang disukai dan dapat menanmkan karakter tertentu melalui permainan musik, olah raga, cerita yang disukainya (Marilyn, 2012).

Ketiga, menyediakan fasilitas materil dan non materil. Pada saat anak berkarya, orang tua menyediakan peralatan yang dibutuhkan oleh anak. Dengan menyediakan peralatan dapat mendorong kreativitas anak. Peralatan yang disediakan seperti peralatan gambar, kanvas, alat musik dan sebagainya.

Keempat, memancing anak untuk meningkatkan kemampuannya dengan cara memberikan tantangan kepada anak dengan memberikan reward dan stimuli. Cara yang dilakukan adalah dengan menantang anak untuk menyelesaikan karyanya dengan memberikan buku baru.

Kelima, memberi motivasi anak untu berkarya. Motivasi dilakukan dengan memberi feedback dan menikmati yang dilakukan. Orang tua dapat memberikan apresiasi dengan cara memujinya.

Keenam, mendampingi anak dalam berkarya dengan cara memberi dukungan dalam bentuk keamanan dan melindungi anak ketika ayah melarang anaknya untuk berkarya seperti melukis. 
Ketujuh, memberi kebebasan kepada anak agar fokus pada bidangnya. Orang tua menghargai tujuan dan memberi kesempatan apa yang menjadi passion anak. Bila sesuai dengan passionnya, maka anak menemukan hal baru dan kreativitasnya menjadi meningkat.

Kedelapan, memiliki rencana ke depan dan mengusahakannya. Orang tua diberi kesempatan sesuai passionnya, melakukan apa yang menjadi ketertarikannya dan memberi kebebsan kepada anak untuk memilih. Orang tua hanya mendukung dan membantu mencarikan informasi dan keputusan yang tepat.

Kesembilan, tidak menekan anak. Orang tua memberi nasehat, namun keputusan tetap harus ada di tangan anak, tidak membandingkan dengan anaklain dan tidak menekan anak. Memberi perbandingan dengan ideal image akan dapat merendahkan self image anak. Akibatnya anak menjadi inferior dan tidak mampu. Selain itu, jangan sampai orang tua membully anak. Ketika anak tidak dalam kondisi baik, menghadapi masalah atau tidak mood, jangan memaksa anak untuk berkarya.

Kesepuluh, melakukan kontrol. Ketika melakukan aktivitas yang disukai, anak memiliki angagement yang tinggi dan anak bisa fokus dalam jangka waktu yang lama ketika sedang melakukan hal yang disenangi. Orang tua harus mengingatkan dan anaknya untuk mejaga kesehatan, makan dan tidur teratur. Meuwissen \& Englund (2015) menjealsakan bahwa kontrol dari orang tua dapat mempengaruhi executive function anak yaitu proses yang dilakukan untuk mengendalikan perilaku diri untuk mencapai target.

Julia Maria van Tiel dan Johan Flores van Tiel (Maria, 2015) menjelaskan pengalamannya sebagai orang tua dari anak berbakat (gifted) dalam bukunya yang berjudul "Perfeksionisme dan Faalangst" (2015). Menurut Maria dan Flores tersebut, sebagai orang tua mereka mengatakan bahwa pentingnya peranan orang tua dalam memahami dan mengembangkan potensi anak berbakat. Bagi Maria dan Flores, peranan orang tua akan lebih optimal adalah membangun kerjasama dengan sekolah. Dalam membangun hubungan kerjasama ini yang peran yang dilakukan orang tua adalah sebagai berikut:

Pertama, orang tua berperan secara aktif dalam membangun hubungan yang harmonis dengan sekolah. Sekolah telah banyak menghadapi anak dengan permasalahan yang beragam, oleh sebab itu orang tua melakukan diskusi atau berdialog dengan guru tentang kelebihan dan kelemahan anaknya. Dengan demikian orang tua juga dapat mempercayai guru untuk membimbing anaknya di sekolah.

Kedua, selanjutnya, orang tua harus mampu mempelajari dan memahami karakteristik anak dan potensi yang dimilikinya agar ia dapat menjelaskan secara tepat kondisi dan potensi anak baik segi positif dan maupun negatifnya.Orang tua juga harus tahu bahwa karakteristik kepribadian anak perfeksionis adalah keras kepala dan sangat menuntut keadilan.

Ketiga, menata atau mengelola sosial emosional anak sebagai tindakan intervensi terapi dan preverensi ketika anak melakukan tindakan faalangst negatif. Faalangst negatif adalah istilah dari bahasa Belanda dan dalam bahasa Inggris disebut fear of failure (Maria \& Flores, 2015). Faalangst lebih banyak dikaitkan dengan munculnya anxiety disorder yang memerlukan bantuan psikiter dan psikolog kinik dengan cognitive behaviour therapy (CBT) dan juga disertai dengan obat-obatan. Faalangst adalah rasa takut bersalah atau rasa takut gagal padahal sebenarnya bisa. Faalangst ada positif dan negatif. Faalangst positif adalah bentuk rasa takut gagal memang diperlukan agar manusia dapat mawas diri dalam rangka mencapai suatu prestasi. Ia dapat menimbang-nimbang apakah ia bisa mendapatkan atau mencapai apa yaang dikerjakan itu.

Pada anak gifted, perkembangan faalangst menjadi berlebihan. Rasa takut salah dan takut gagal itu berkembang menjadi luar biasa yang dapat menghambat perkembangan prestasi yang sebetulnya ia lakukan dengan sangat baik. Inilah yang disebut dengan faalangst negatif. Faalangst negatif muncul dari masalah perfeksionisme. Masalah yang muncul terkait dengan faalangst negatif adalah konsep diri yang negatif, tidak percaya diri, sensitif luar biasa, kecemasan yang luar biasa depresivitas, dan sering keluar kata-kata "lebih baik bunuh diri saja". Akhirnya ia tidak mampu 
mempresentasikan tugas di kelas bahkan tidak mau bertanding padahal ia adalah anak juara pertama.

Untuk megatasinya, ibu dan ayah harus harus mendukung keberbakatannya. Si anak diajarkan bagaimana mengatasi faalangst negatif ini. Karena kepintarannya ia bisa menyembunyikan faalangstnya tersebut. Misalnya pada kasus ia mendapatkan nilai jelek, ia akan melaporkan bahwa gurunya tidak bisa mengajar dengan baik sehingga ia tidak mengerti. Karena tidak percaya diri dan cemas yang berlebihan akan menghambat perkembangan potensi dirinya. Orang tua harus mampu menaikan kepercayaan diri anak dengan cara menunjukan dirinya merupakan anak yang berpotensi tinggi yaitu misalnya sangat handal dengan komputer.

Keempat, orang tua mengajak untuk memahami situasi. Bagian ini adalah bagian yang sulit, karena anak yang eigenwijs (hanya mengikuti jalan pikirannya sendiri). Ia tidak mau menerima pendapat orang lain. Mengajak memahami situasi adalah membuka konfrontasi dengan anak. Caranya adalah dengan melihat mood anak apakah dapat diajak bicara pada hari itu. Bagi anak yang masih kecil, orang tua bisa mengaturnya dengan cara mengarahkan, melarang dengan penjelasan praktis. Namun, semakin besar anak cara ini sudah tidak mapan lagi. Orang tua perlu mempersiaapkan diri anaknya agar lebih mandiri. Caranya adalah ia harus memahami masalah yang ada pada dirinya sendiri dan mampu mengatasinya tanpa banyak bantuan orang lain hingga dewasa nanti betul-betul mandiri. Apabila orang tua dapat melihat area apa saja yang menghambat perkembangan sosio emosional anak, maka dapat mengarahkannya, dan melatih bagaimana caranya mengatasi hambatan tersebut. Untuk mengetahui area apa saja yang menjadi objek perfeksionisme anak berbakat dapat dilihat pada tabel di bawah ini sebagaimana yang dicontohkan oleh Roz Shafran, dkk (2010) dalam (Maria, 2015).

Tabel 1. Area Perfeksionisme, Pikiran Yang Khas dan Perilaku Anak Berbakat

\begin{tabular}{|c|c|c|}
\hline Area Perfeksionisme & Pikiran & Perilaku \\
\hline Makan & $\begin{array}{l}\text { Saya tidak boleh makan } \\
\text { dengan kadar lemak yang } \\
\text { tinggi }\end{array}$ & $\begin{array}{l}\text { Menjaga makanan dengan } \\
\text { ketat }\end{array}$ \\
\hline Bentuk tubuh & $\begin{array}{l}\text { Saya harus mencapai } \\
\text { ukuran nomor yang ideal } \\
\text { (Misal no 6) agar tampak } \\
\text { bagus }\end{array}$ & $\begin{array}{l}\text { Menjaga makanan secara } \\
\text { ketat dan memperbanyak } \\
\text { latihan/olah tubuh }\end{array}$ \\
\hline Berat badan & $\begin{array}{l}50 \mathrm{~kg} \text { adalah berat badan } \\
\text { ideal untuk saya }\end{array}$ & $\begin{array}{l}\text { Menjaga makanan secara } \\
\text { ketat dan memperbanyak } \\
\text { latihan/olah tubuh }\end{array}$ \\
\hline Penampilan sosial & $\begin{array}{l}\text { Saya harus tampak kocak } \\
\text { dan pintar }\end{array}$ & $\begin{array}{l}\text { Mengulang-ngulang } \\
\text { dagelan dan cerita }\end{array}$ \\
\hline $\begin{array}{l}\text { Memeriksa kunci dan } \\
\text { peralatan }\end{array}$ & Saya harus yakin 100 persen & Selalu memeriksa ulang \\
\hline Mengatur sesuatu & $\begin{array}{l}\text { Segala sesuatunya harus } \\
\text { teratur }\end{array}$ & $\begin{array}{l}\text { Setiap hari mengatur dan } \\
\text { menyususn objek sasaran }\end{array}$ \\
\hline Organisasi & $\begin{array}{l}\text { Membuat daftar supaya } \\
\text { segalanya terorganisasi }\end{array}$ & $\begin{array}{l}\text { Membuat daftar } \\
\text { panjang }\end{array}$ \\
\hline Kebersihan rumah & $\begin{array}{l}\text { Rumah saya harus selalu } \\
\text { bersih }\end{array}$ & $\begin{array}{l}\text { Membersihkan } \\
\text { berlebihan }\end{array}$ \\
\hline Penampilan & $\begin{array}{l}\text { Penampilan saya harus } \\
\text { benar-benar sempurna }\end{array}$ & $\begin{array}{l}\text { Selalu menggunakan make- } \\
\text { up dan pakaian licin } \\
\text { bersetrika }\end{array}$ \\
\hline Hygiene & Tangan saya harus selalu & Mencuci \\
\hline
\end{tabular}




\begin{tabular}{llll}
\hline & bersih & menerus & \\
\hline Penampilan artistik & $\begin{array}{l}\text { Saya perlu menghasilkan } \\
\text { artistik yang hebat }\end{array}$ & $\begin{array}{l}\text { Membuat lukisan terus } \\
\text { menerus }\end{array}$ \\
\hline Penampilan musik & $\begin{array}{l}\text { Saya tidak boleh salah } \\
\text { notasi dalam penampilan }\end{array}$ & Menghindari penampilan \\
\hline $\begin{array}{l}\text { Penampilan dalam olah } \\
\text { raga }\end{array}$ & $\begin{array}{l}\text { Agar penampilan sempurna } \\
\text { saya harus berlatih lebih } \\
\text { keras }\end{array}$ & $\begin{array}{l}\text { Berlatih melebihi dari apa } \\
\text { yang dianjurkan pelatih }\end{array}$ \\
\hline Penampilan akademik & $\begin{array}{l}\text { Saya harus berprestasi } \\
\text { setidaknya } 80 \%\end{array}$ & $\begin{array}{l}\text { Menggunakan } \\
\text { banyak untuk mengedit } \\
\text { tugas }\end{array}$ \\
\hline
\end{tabular}

Sumber: Shafran (2010) dalam Maria \& Flores (2015: 146-147)

Kelima, orang tua berkompromi, berdiskusi dan persuasi menghadapi anak. Dalam hal ini orang tua diharapkan memiliki kesabaran yang luar biasa karena apa yang disampikan orang tua tida akan begitu saja diterima. Anak selalu menuntut bukti yang dipercayainya terlebih dulu bahwa yang kita tawarkan adalah benar. Situasi dan karakteristik anak seperti ini sering membawa konflik bahkan kekerasan terhadap anak. Dengan adanya kompromi, diskusi dan persuasi ini anak akan mejadi percaya diri dan mau mengerjakan sesuatu yang berkaitan dengan potensi dirinya.

Keenam, menghargai potensi anak. Faalangst negatif secara terus menerus akan menyebabkan rasa percaya diri yang kurang sehingga memunculkan konsep diri yang negatif. Anak merasa bahwa ia anak yang bodoh, merasa jelek, tidak berguna, dan sebagainya. Kondisi ini menyebabkan ia tidak dapat melihat potensi dirinya. Padahal sebanarnya ia mampu dan mempunyai potensi. Untuk itu, orang tua perlu menghargai potensi anaknya agar ia bisa melihat potensinya sendiri dan dengan potensi yang dimilikinya itu dapat menghasilkan potensi yang baik.

Ketujuh, selalu memberi dukungan. Dukungan yang diberikan orang tua adalah dengan cara melihat gejala secara positif. Orang tua banyak belajar dari para guru dan teman-temannya dari pandangan yang negatif menjadi positif. Berkenalan dengan guru yang sangat sabar dan perhatian dan menerima masukan dari berbagai pihak terkait dengan potensi yang dimiliki anak. Orang tua dapat berbagi pengalaman karena banyak berdialog dan berdiskusi sehingga memberi pemahaman yang lebih mendalam tentang kondisi dan potensi anaknya. Karena bisa saja orang tua tidak mengenal bagaimana potensi anak yang sebenarnya.

Keelapan, menerima kesalahan dan kekalahan. Orang tua mengajarkan bahwa sebuah kesalahan adalah sebuah proses belajar. Jika anak mendapatkan dirinya mendapatkan kegagalan, maka orang tua mengajaknya mengevaluasi apa yang bisa diperbuat di lain kesempatan untuk mendapatkan hasil sebagaimana yang diinginkan. Orang tua bersama anak lalu mencari alternatif cara yang dapat digunakan. Dengan demikian, ia akan belajar dari kesalahan dan kekalahannya dan belajar mencari jalan keluar memperbaiki cara yang menyebabkan kegagalannya. Anak akan bergerak dari seorang yang perfeksionisme ke seorang yang optimalis.

Dari penjelasan di atas dapat dipahami bahwa orang tua dapat berperan sebagai educator, motivator, fasilitator, supporter, dan role model dalam mengembangkan potensi anak berbakat. Peranan yang dijalankan oleh orang tua relevan dengan prinsip teori belajar humanistik. Perhatian kaum humanis adalah pengembangan pada potensi diri anak. Atau dengan kata lain, penganut humanistik mencakup teori pendidikan pada child-centered. Pendidik seperti orang tua dan guru harus membangun iklim kepercayaan dan rasa hormat yang memungkinkan anak belajar memutuskan apa dan bagaimana mereka membentuk dirinya sendiri. Anak gifted adalah anak yang memiliki potensi yang luar biasa, dan potensi tersebut harus dipahami oleh orang tua dan guru di sekolah agar ia dapat mengembangkan potensinya tersebut.

Para pendidik (orang tua dan guru) harus menjadi fasilitator di rumah atau kelas dan harus menjadikan tempat itu untuk menyalurkan rasa keinginantahuan dan hasrat untuk belajar. 
(Sadulloh, 2006). Dalam pandangan humanistik, pendidik selalu memotivasi anak agar belajar mandiri. Terhadap anak berbakat, orang tua perlu mempersiapkan diri anaknya agar lebih mandiri. Caranya adalah memahami masalah yang ada pada anaknya sendiri dan si anak mampu mengatasinya tanpa banyak bantuan orang lain sehingga jika telah dewasa anaknya menjadi mandiri. Orang tua dapat melihat area apa saja yang menghambat perkembangan sosio emosional anak sehingga dapat mengarahkannya, dan melatih bagaimana caranya mengatasi hambatan tersebut.

Salah seorang teori pendidikan humanistik bernama Carl Rogers mengemukakan prinsipprinsip humanistik dalam bukunya Freedom to Learn (Pohan, 2019) sebagai berikut:

a. Manusia mempunyai kemampuan belajar secara alami.

b. Belajar signifikan bila subject matter yang dipelajari anak relevan dengan tujuan anak itu sendiri.

c. Belajar menyangkut perubahan dalam persepsi mengenai dirinya yang dianggap mengancam dirinya sehingga ditolak oleh anak

d. Tugas-tugas belajar yang mengancam diri adalah lebih mudah dirasakan dan diasimilasikan apabila ancaman-ancaman dari luar semakin kecil.

e. Apabila ancaman terhadap diri anak rendah, maka pengalaman dapat diperoleh dengan cara yang berbeda-beda dan terjadilan proses belajar.

f. Belajar yang bermakna diperoleh anak dengan melakukannya.

g. Belajar diperlancar bagaimana anak dilibatkan dalam proses belajar dan ikut bertanggung jawab terhadap proses belajar tersebut.

h. Belajar atas inisiatif sendiri yang melibatkan pribadi anak seutuhnya baik kognitif, afektif dan psikomotor.

i. Kepercayaan terhadap diri sendiri, kemerdekaan, kreativitas lebih mudah dicapai jika anak mawas diri dan mengkritik dirinya sendiri, serta penilaian orang lain.

j. Belajar mengenai proses belajar merupakan suatu keterbukaan secara terus menerus terhadap pengalaman dan penyatuan ke dalam diri anak mengenai proses perubahan tersebut.

Prinsip-prinsip belajar Rogers di atas dapat diaplikasikan dalam mengkaji proses belajar yang dialami anak berbakat yaitu:

1. Anak berbakat memiliki kemampuan secara alami baik secara akademik dan non akademik. Untuk itu bakat atau potensi alami tersebut harus diperhatikan dan dikembangkan oleh para pendidik (orang tua dan guru).

2. Belajar harus relevan dengan kebutuhan dari anak berbakat yang memiliki kemampuan, namun juga memiliki kelemahan sehingga harus relevan dengan kemampuan dan kelemahan anak tersebut.

3. Anak berbakat memiliki kelemahan dalam konsep dirinya yang perfeksionisme dan faalangst negatif sehingga dengan belajar harus dapat merubah konsep dirinya yang perfeksionis dan faalangst negatif itu.

4. Anak berbakat akan dapat mengerjakan tugas-tugas sekolahnya bila tidak adanya tekanan dari guru, orang tua dan teman-temannya.

5. Proses belajar anak berbakat akan lancar dan tidak mengalami hambatan bila tidak ada gangguan dan tekanan pihak luar seperti guru, orang tua, dan teman-temannya, seperti membully, tidak menghargai, tidak memberi kesempatan dan sebagainya.

6. Belajar akan bermakna jika anak berbakat itu sendiri yang menjalaninya dengan berbagai pengalaman belajar yang dilakukannya.

7. Anak berbakat akan mudah dan lancar dalam belajar jika dia dilibatkan dalam proses belajar tersebut dan diajarkan bagaimana mereka bertanggung jawab dengan apa yang dikerjakannya.

8. Anak berbakat dilatih belajar dengan inisiatif sendiri sehingga setiap proses belajar yang dilaluinya dapat mengembangkan aspek kognitif afektif dan psikomotor. Anak berbakat dapat mengalami perkembangan sosio emosional bila tidak dapat dikendalikan dan diatur dengan baik oleh pendidik. 
9. Anak berbakat dapat dikembangkan kreativitas, kebebasannya dalam belajar sehingga ia dapat menilai kelemahan dan kelebihan dirinya sendiri dan orang lain. Dengan demikian kepercayaan dirinya yang kurang dapat ditingkatkan untuk menjadi orang yang percaya dengan kemampuan yang dimiliknya tersebut.

10. Untuk mengembangkan potensi anak berbakat, dia harus terus belajar secara berkelanjutan dengan melibatkannya dalam berbagai pengalaman belajar sehingga proses tersebut dapat membentuk dirinya secara utuh.

\section{Kesimpulan}

Orang tua adalah sebagai agen utama yang paling berperan dalam mengembangkan potensi anak berbakat. Sebagai anak berbakat (gifted) memiliki kemampuan yang luar biasa di bidang akademik dan non akademik. Namun, dari kemampuan itu tidak bisa hanya dianggap sebagai sesuatu yang positif saja, karena kelebihan yang mereka miliki sekaligus menjadi kelemahan sehingga banyak permasalahan yang muncul dengan adanya kelebihan dan kelemahannya. Oleh karena itu orang tua harus peduli, cermat dan aktif menyikapi dan berperan mengembangkan potensi anaknya. Lalu menjadi orang tua yang cerdas ketika menghadapi kelemahan dan masalah yang ditemui dalam pengembangan potensi tersebut. Peran orang tua sangat dibutuhkan sebagai pendidik, supporter, fasilitator, motivator dan role model bagi anaknya agar anak mengalami perkembangan dengan baik, terutama perkembangan potensi anak berbakat. Peran yang dijalankan oleh orang tua tersebut sangat relevan dengan teori pendidikan humanistik yang melihat anak sebagai pusat, perhatian pada pengembangan potensi anak, orang tua sebagai fasilitator, motivator dan supporter pengembangan potensi anaknya.

\section{Daftar Pustaka}

Danim, S. (2002). Menjadi Peneliti Kualitatif. Bandung: Pustaka Setia.

Elly M. Setiadi, U. K. (2011). Pengantar Sosiologi : Pemahaman Fakta dan Gejala Permasalahan Sosial: Teori, Apllikasi dan Pemecahannya. Jakarta: Kencana Prenada Media Group.

Gagné, F. (2006). Transforming Gifts into Talents: The DMGT as a Developmental Theory. Dalam N. Colangelo, \& G. A. Davis, Handbook of Gifted Education, (3rd ed). Boston: Allyn and Bacon.

Hawadi, L. (2000). Hubungan antara Ciri-Ciri Keberbakatan pada Alat Identifikasi Siswa Berbakat dengan Alat Tes Psikologik, dan Prestasi Belajar (Penelitian pada Murid-Murid kelas IV Sekolah Dasar Kecamatan Mampang Prapatan-Jakarta Selatan). FIPSIUI.TALENTED STUDENTS Motivation.

Maria, J. van T. \& J. F. van T. (2015). Perfeksionisme \& Faalangs. Jakarta: Prenada Media Grup.

Marilyn, W. (2012). The Child Development Project: Building Character by Building Communit. Action in Teacher Education, 20(4), 59-69.

Masruroh, H \& Widayat, I. . (2014). Strategi Orang Tua dalam mengembangkan Kreatifitas Anak Gifted. Jurnal Psikologi Pendidikan dan Perkembangan, 3(2), 213-220.

Mulyadi, S. (2019). Psikologi Pendidikan dengan Pendekatan Teori-Teori Baru dalam Psikologi. Depok: Rajawali Pers.

Munadar, U. (2012). Pengembangan Kreativitas Anak Berbakat. Jakarta: Rineka Cipta.

Nazir, M. (1988). Metode Penelitian. Jakarta: Ghalia Indonesia.

Pohan, J. E. (2019). Filsafat Pendidikan Teori Klasik Hingga Postmodernisme dan Problematikanya di Indonesia. Jakarta: Rajawali Pers.

Rusdayanti, I. G. A. D. (2019). Penyesuaian Diri Anak Berbakat Intelektual dengan Pola Asuh Otoritarian. Jurnal Psikologi Udayana, 6(1), 12-40.

Sadulloh, U. (2006). Pengantar Filsafat Pendidikan. Bandung: Alfabeta.

Santrock, J. W. (2011). Educational psychology (5th ed). New York: McGraw-Hill. 
Soekanto, S. (2009). Sosiologi Suatu Pengantar. Jakarta: Rajawali Pers.

Wahab, Rachmat. (1997). Meningkatkan Keterlibatan Orang Tua dalam Pembinaan Keterbakatan. Jurnal Dinamika Pendidikan, 1(IV), 45-58.

Wahab, Racmat. (2005). Peranan Orang Tua dan Pendidik dalam Mengoptimalkan Potensi Anak Berbakat Akademik. Makalah Seminar Nasional di Universitas Diponegoro Semarang. Semarang.

Wandansari, Y. (2012). Faktor Protektif pada Penyesuaian Sosial Anak Berbakat. Jurnal Insan Media Psikolog, 13(2).

Widayat, S. \& I. W. (2016). Strategi Orang Tua dalam Mengoptimalkan Potensi Seni Anak Berbakat Istimewa. Jurnal Psikologi dan Perkembangan, 5(1), 1-15. 